\title{
Significant Applications of Big Data in COVID-19 Pandemic
}

\author{
Abid Haleem $^{1} \cdot$ Mohd. Javaid $^{1} \cdot$ Ibrahim Haleem Khan $^{2} \cdot$ Raju Vaishya $^{3}$
}

Received: 3 April 2020 / Accepted: 27 April 2020 / Published online: 7 May 2020

(c) Indian Orthopaedics Association 2020

\section{Dear Editor,}

New cases of COVID-19 (Coronavirus) are increasing rapidly at astonishing rates globally; more than 1.2 billion people have developed an infection and out of these, around 65,000 have died of this disease, until today. This immediate burst of cases and their health data have created a vital source of information and knowledge. There is an immediate requirement to store such a large amount of data of these cases, using different data storage technologies. These data are used to undertake research and development about the virus, pandemic and measures to fight this virus and its after-effects. Big data is an innovative technology which can digitally store a large amount of data of these patients. It helps to computationally analyse to reveal patterns, trends, associations and differences. It can also help in revealing the insights into the spread and control of this virus. With detailed data capturing capability, big data can be used gainfully to minimise the risk of spreading this virus $[1,2]$.

Mohd. Javaid

mohdjavaid0786@gmail.com

https://scholar.google.co.in/citations?user=rfyiwvsAAAAJ\&hl=en

Abid Haleem

haleem.abid@gmail.com

https://scholar.google.co.in/citations?user=40471

48AAAAJ\&hl=en

Ibrahim Haleem Khan

ibrahimhaleemkhan.ihk@gmail.com

Raju Vaishya

raju.vaishya@gmail.com

https://scholar.google.co.in/citations?user

$=2 \mathrm{Lu} 3 \mathrm{gQ} 0 \mathrm{AAAAJ} \& \mathrm{hl}=\mathrm{en}$

1 Department of Mechanical Engineering, Jamia Millia Islamia, New Delhi 110025, India

2 School of Engineering Sciences and Technology, Jamia Hamdard, New Delhi, India

3 Department of Orthopaedics, Indraprastha Apollo Hospital, SaritaVihar, Mathura Road, New Delhi 110076, India
Big data technology can store a massive amount of information about these people infected with this COVID-19 virus. It helps in understanding the nature of this virus in detail. The data obtained can further be trained over again for developing future preventive methods. This technology is used to store the data of all types of cases (infected, recovered and expired) affected by COVID-19. This information can be effectively used for case identification and helping to allocate the resources for better protection of public health $[3,4]$.Several modalities of digital data including patient location, proximity, patient-reported travel, co-morbidity, patient physiology and current symptoms can be digitised and used for generating actionable insights at both community and demography levels. Table 1 provides significant applications of big data in COVID-19 pandemic.

Big data provides a massive amount of information to the scientists, health workers, epidemiologists and help them to make informed decision to fight with the COVID-19 virus. These data can be used to track the virus on a global basis continuously and to create innovation in the medical field $[5,6]$. It can help to forecast the impact of COVID-19 in a particular area and the whole population. It helps in research and development of new treatment procedure. Big data can also provide possible sources and opportunities for the people and, thus, help to handle the stressful situation. Overall, this technology provides data to undertake analysis of the disease transmission, movement, and health monitoring and prevention system.

In the surgical speciality of Orthopaedics, the big data can help in the predictive analysis of Orthopaedic and Trauma surgery, from the available data. Trauma mortality and morbidity mimic the current pandemic, and there may be cross-fertilisation of ideas from it. This technology is helpful in keeping record of the orthopaedic patients, which can influence positive and correct clinical decision-making. It can, therefore, increase the performance by a better understanding of the treatment procedures from the appropriate captured data. Big data is a blessing for conducting the clinical trials, to speed up the treatment process by analysing the patient's record. 
Table 1 Significant applications of big data in COVID-19 pandemic

\begin{tabular}{|c|c|c|}
\hline S. No. & Applications & Description \\
\hline 1 & Identification of infected cases & $\begin{array}{l}\text { It is capable of storing the complete medical history of all patients, due to its capabil- } \\
\text { ity of storing a massive amount of data } \\
\text { By providing the captured data, this technology helps in identification of the infected } \\
\text { cases and undertake further analysis of the level of risks }\end{array}$ \\
\hline 2 & Travel history & $\begin{array}{l}\text { Used to store the travel history of the people to analyse the risk } \\
\text { Helps to identify people who may be in contact with the infected patient of this virus }\end{array}$ \\
\hline 3 & Fever symptoms & $\begin{array}{l}\text { Big data can keep the record of fever and other symptoms of a patient and suggest if } \\
\text { medical attention is required } \\
\text { Helps to identify the suspicious cases and other misinformation with the appropriate } \\
\text { data }\end{array}$ \\
\hline 4 & Identification of the virus at an early stage & $\begin{array}{l}\text { Quickly helps to identify the infected patient at an early stage } \\
\text { Helps to analyse and identify persons who can be infected by this virus in future }\end{array}$ \\
\hline 5 & Identification and analysis of fast-moving disease & $\begin{array}{l}\text { Helps to effectively analyse the fast-moving disease as efficiently as possible } \\
\text { Potential to handle appropriate information regarding the disease }\end{array}$ \\
\hline 6 & Information during lockdown & $\begin{array}{l}\text { This technology collects information regarding this virus during the lockdown } \\
\text { Track and monitor the movement of people and entire health management }\end{array}$ \\
\hline 7 & People entered or leaving the affected area & $\begin{array}{l}\text { It helps to analyse the number of people entered or leaving from the affected city } \\
\text { With these vast amount of data, health specialist can quickly identify the chances of } \\
\text { the virus in those peoples }\end{array}$ \\
\hline 8 & Faster development of medical treatments & $\begin{array}{l}\text { Assist in fast-tracking the development of new medicines and equipment needed for } \\
\text { current and future medicinal needs } \\
\text { Provides previous data of virus inhabited or spread and, thus, helps in gaining a giv- } \\
\text { ing advantage over newer pandemic/epidemic with previously analysed results }\end{array}$ \\
\hline
\end{tabular}

Big data analytics will act as a medium for tracking, controlling, research and prevention of COVID-19 as a pandemic. It will diversify manufacturing, enhance vaccine development on more profound means, with absolute knowledge. Prevalent modelled data helps in understanding and offering an edge over the other process like corresponding homology models predicted by fold and function assignment system server for each target protein were downloaded from Protein Data Bank, for predicting the COVID-19 cure and identifying the symptoms associated with it $[7,8]$. Big data provides the insights and analyses with the factors leading to better containment of the infected persons. China suppressed the COVID-19 with the help of data collection and implementing it with AI leading towards a low rate of spread. There are several big data components to this pandemic where AI can play a significant role like in biomedical research, natural language processing, social media, and mining the scientific literature.

The surgical specialty of Orthopaedics requires excellent surgical skills, clinical acumen, reasonable physical strength and better understanding. As a complement to these requirements, new technologies (e.g., AI) have been are adopted in the last few years, which has helped to create innovations in the field of Orthopaedics and has also provided positive impact in the treatment and surgery [9]. Significant changes and innovations are possible with the help of new technologies like big data, AI and 3D printing.
These technologies provide opportunities for better service and patient outcomes [10].

In some places, the big data provides information to identify the suspected cases of this virus. It helps to provide an efficient way to prevent the illness and extract other valuable information. In future, big data will help the public, doctors, other healthcare professionals and researchers to track this virus and analyse the infection mechanism of COVID-19. Data provided help to examine how this infection can be slowed or eventually prevented, and help to optimise the allocation of resources and accordingly contributing to taking appropriate and timely decisions. With the assistance of this digital data storing technology, doctors and scientists can also develop a convenient and efficient method of COVID-19 testing.

\section{Compliance with Ethical Standards}

Conflict of interest The authors declare that they have no confict of interest to disclose.

Ethical standard statement This article does not contain any studies with human participants or animals, performed by any of the authors.

Informed consent For this type of study a formal consent is not required. 


\section{References}

1. Wang, C. J., Ng, C. Y., \& Brook, R. H. (2020). Response to COVID-19 in Taiwan: big data analytics, new technology, and proactive testing. JAMA. https://doi.org/10.1001/jama.2020.3151.

2. Bai, Y., Yao, L., Wei, T., Tian, F., Jin, D. Y., Chen, L., et al. (2020). Presumed asymptomatic carrier transmission of COVID19. JAMA. https://doi.org/10.1001/jama.2020.2565.

3. Anshari, M., Almunawar, M. N., Lim, S. A., \& Al-Mudimigh, A. (2019). Customer relationship management and big data enabled: personalisation \& customisation of services. Applied Computing and Informatics, 15(2), 94-101.

4. MacLaren, G., Fisher, D., \& Brodie, D. (2020). Preparing for the most critically ill patients with COVID-19: the potential role of extracorporeal membrane oxygenation. JAMA. https://doi. org/10.1001/jama.2020.2342.

5. Xia, W., Sanyi, T., Yong, C., Xiaomei, F., Yanni, X., \& Zongben, X. (2020). When will be the resumption of work in Wuhan and its surrounding areas during COVID-19 epidemic? A data-driven network modelling analysis. SCIENTIA SINICA Mathematica. https://doi.org/10.1360/SSM-2020-0037.

6. Haleem, A., Javaid, M., \& Vaishya, R. (2020). Effects of COVID 19 pandemic in daily life. Current Medicine Research and Practice. https://doi.org/10.1016/j.cmrp.2020.03.011.
7. Amini, S., Gerostathopoulos, I., \& Prehofer, C. (2017). Big data analytics architecture for real-time traffic control. In: 2017 5th IEEE international conference on models and technologies for intelligent transportation systems (MT-ITS), 26 Jun 2017 (pp. 710-715).

8. Wu, C., Liu, Y., Yang, Y., Zhang, P., Zhong, W., Wang, Y., et al. (2020). Analysis of therapeutic targets for SARS-CoV-2 and discovery of potential drugs by computational methods. Acta Pharmaceutica Sinica B. https://doi.org/10.1016/j.apsb.2020.02.008.

9. Poduval, M., Ghose, A., Manchanda, S., Bagaria, V., \& Sinha, A. (2020). artificial intelligence and machine learning: a new disruptive force in orthopaedics. Indian Journal of Orthopaedics, 54, $1-4$.

10. Shetty, N. (2020). Technology and innovation: the game changer of the next decade. Indian Journal of Orthopaedics, 54, 107-108.

Publisher's Note Springer Nature remains neutral with regard to jurisdictional claims in published maps and institutional affiliations. 